\title{
A primal incrimination of Cedecea davisae with post-prostatectomy urinary tract infection in Nigeria
}

\author{
D. E. AGBONLAHOR ${ }^{1,3^{*}}$, J. I. EHIAGHE ${ }^{1}$, O. A. EREMWANARUE ${ }^{1}$, \\ A. F. EHIAGHE ${ }^{1}$, F. E. OVIASOGIE ${ }^{2}$, R. I. IYEN ${ }^{1}$, E. C. OGBU ${ }^{1}$, P. E. IKHIUWU ${ }^{1}$, \\ M. O. OSEJI ${ }^{1}$, S. ABBEY ${ }^{3}$ and M. S. TATFENG ${ }^{3}$ \\ ${ }^{1}$ Lahor Research Laboratories and Medical Centre, 121, Old Benin Agbor Road, \\ Ohovbe-Ogbeson Quarters, Benin City, Edo State, Nigeria. \\ ${ }^{2}$ Department of Microbiology, Faculty of Life Sciences, University of Benin, Benin City. Edo State, Nigeria. \\ ${ }^{3}$ Department of Medical Laboratory Science, Faculty of Health Sciences, \\ Niger Delta University, Amassoma, Baylesa State, Nigeria. \\ *Corresponding author; E-mail: deagbonlahor@yahoo.com
}

\begin{abstract}
Cedecea species are recent members of the family Enterobacteriaceae and are rarely incriminated in human infections. A patient with protracted urinary tract infection, post-prostatectomy, was referred to Lahor Research Laboratories, Benin City, Nigeria for routine culture and susceptibility testing. Three consecutive mid-stream urine samples from him yielded pure, heavy, growths of an apparently same Gram negative, nonspore forming, non-capsulated, motile, rod-shaped bacterium, which was lipase, citrate, methyl red, KCN, $\mathrm{ONPG}$, arginine and ornithine decarboxylase positive. It was oxidase, urease, $\mathrm{H}_{2} \mathrm{~S}$, indole, gelatinase, deoxyribonuclease and phenylalanine deaminase negative. It fermented glucose, xylose, sucrose, salicin, maltose mannitol, and lactose but was negative arabinose, inositol, dulcitol, raffinose, rhamnose and melibiose. It exhibited multiple antibiotic resistances to augmentin, gentamicin, ofloxacin, cefixime, ciprofloxacin, ceftazidime and cefuroxime but was very sensitive to imipenem and moderately susceptible to nitrofurantoin. The isolate was identified phylogenetically as Cedecea davisae. It possessed plasmid at $48.5 \mathrm{~kb}$ and harboured SHV, TEM, and gyrA antibiotic-resistance genes, which were either plasmid-mediated, chromosomal-mediated or both. To the best of knowledge, this is the first report on the incrimination of this organism with human infection in Nigeria. It was concluded that the paucity of reports on Cedecea species as aetiologic agents of human infections could be as a result of the difficulty in recognizing and characterizing this recently described pathogen, particularly in low resource laboratories, coupled with the fact that Laboratorians and Physicians are yet to be fully aware of the emerging clinical significance of this "relatively new" organism.
\end{abstract}

(C) 2018 International Formulae Group. All rights reserved.

Keywords: Cedecea davisae, Difficult-To-Treat, UTI, Nigeria.

\section{INTRODUCTION}

The genus Cedecea is a relatively new member of the family Enterobacteriacea and its name is an abbreviation for the Centers for
Disease Control (CDC), where the initial group of isolates, "Enteric Group 15", were first discovered (Michael and Abbatt, 2006). Five species are currently believed to be 
members of the genus, three of which, Cedecea davisae, C. lapagei and C. neteri, have so far been fully identified (Dalamago and Vrioni, 2011).

They are Gram negative, oxidase negative, lipase positive, non-sporulating motile rod-shaped bacteria. A literature search reveals that there are limited reports that have incriminated Cedecea spp. as human pathogens. Members of the genus have been isolated from human clinical specimens including urine (Cekin et al., 2014), blood (Dalamago et al., 2008a; Dalamago et al., 2008b; Abate et al., 2011; Akinosoglou et al., 2012; Peretz et al., 2013;), Ulcer (Dalamago et al., 2008b, Mawardi et al., 2010; Biswal and Hussan, 2015), sputum (Yetkin et al., 2008; Bozkurt, 2014).

As a result of the few available reports, coupled with the relatively recent description of the genus, most clinical microbiologists, pathologists, laboratory scientists and other laboratory diagnosticians may be slow to recognize the emerging clinical significance of this genus. From an otherwise routine referral, this report presents the isolation and characterization of an unfamiliar bacterium, identified as Cedecea davisae from urine specimens of a 76 years old post-prostatectomy patient.

\section{MATERIALS AND METHODS}

\section{Urine bacteriology}

A total of four clean-catch mid-stream urine specimens, one on each visit, were collected from the patient and were aseptically inoculated onto Cysteine Lactose Electrolyte Deficient (CLED) agar, MacConkey Agar (MCA) and Blood Agar (BA) media and incubated at $37{ }^{\circ} \mathrm{C}$ aerobically for $24 \mathrm{hrs}$. Colonial morphologies on media were observed and the colonies were counted using colony counter. Counts of $\geq 10^{5}$ per ml were considered as significant growth (Cheesbrough et al., 2006).

\section{Ethical approval}

The urine samples were collected after the necessary routine pre-sampling explanations, prior to securing the patient's understanding and consent. Ethical clearance to publish these findings was obtained from the Ethics Committee of the Lahor Research Laboratories and Medical Centre (Ref. No. LRL/005/035).

\section{Microscopic examination of urine sample}

Two loopfuls of uniformly mixed uncentrifuged urine sample were aseptically placed on a clean grease-free slide and covered with a cover slip. It was examined microscopically to detect the presence of pus cell, epithelial cell, red blood cell, yeast cell, crystal cells and cast cells, using 10x and $40 \mathrm{x}$ objectives with denser iris closed sufficiently to give good contrast.

\section{Biochemical characterization of isolate}

After overnight incubation, the colonies were morphologically described. Standard identification procedures including Gram staining reaction, motility, lipase, oxidase, urease, sugar fermentation, and indole production tests were carried out on the isolate. IMViC (Indole, Methyl red, VoguesProskauer, and Citrate) tests were also carried out to characterize the uropathogen (Olugbue and Onouha 2011; Ehiaghe et al., 2016).

\section{Antibiotic susceptibility testing}

Antimicrobial susceptibility testing was carried out on the isolate using the KirbyBauer disc diffusion method in accordance with the National Committee for Clinical Laboratory Standards guideline (National Committee for Clinical Laboratory Standards, 2003). Briefly, colonies were suspended in 
sterile normal saline and the inoculum density was adjusted to 0.5 McFarland turbidity standards. A sterile cotton wool swab was inserted into the standardized growth suspension, rotated with firm pressure on the inside wall of the test tube to remove excess fluid and then used to swab the surface of a freshly prepared dried Mueller- Hinton agar plate. The antimicrobial discs used included nitrofurantoin (Nit $300 \mu \mathrm{g}$ ), ceftazidime (Caz $30 \mu \mathrm{g}$ ), gentamicin (GN $30 \mu \mathrm{g}$ ), ofloxacin (Ofx $5 \mu \mathrm{g}$ ), ciprofloxacin (Cpr $5 \mu \mathrm{g}$ ), Imipenem ( $\operatorname{lmp} 10 \mu \mathrm{g})$, cefuroxime (Crx 30 $\mu \mathrm{g}$ ), cefixme (Cxm $5 \mu \mathrm{g}$ ), ceftriaxone (Ctx 25 $\mu \mathrm{g}$ ) and augmentin (Aug, $30 \mu \mathrm{g}$ ). The discs were placed on the surface of the inoculated Muller Hinton agar and incubated at $37{ }^{\circ} \mathrm{C}$ for 24 hours. Diameters of zones of inhibition were measured to the nearest millimeter (Clinical and laboratory standards institute, 2009).

\section{Molecular assays \\ DNA extraction from bacteria isolate}

Single colony from Nutrient agar plate was inoculated into $3 \mathrm{ml}$ of Laura broth (Miller) and incubated at $37^{\circ} \mathrm{C}$ overnight with constant agitation at $120 \mathrm{rpm}$. Aliquot of 1.5 $\mathrm{ml}$ of the overnight culture was transferred into a microcentrifuge tube and centrifuged at $13000 \mathrm{rpm}$ for 3 minutes. The pellet was resuspended in $200 \mu 1$ of nuclease free water and DNA was extracted using the ZR Fungi/Bacterial DNA MiniPrep (Zymo Research, Irvine, CA) as previously described (Ehiaghe et al., 2013).

\section{Molecular detection of antibiotic resistant} genes gyrA, TEM, SHV and aac (3)-II

Amplification was carried out using OneTaq one-step PCR mix (catalog No. NEB M0486S), supplied by New England Bio Labs Incorporation (Massachusetts), according to the manufacturer's specification. Forward and reverse primers were used to target gyrA,
TEM, SHV and aac (3)-II resistant genes as shown in Table 1 using Applied Biosystem 9700 thermal cycler PCR machine at the Lahor Research Laboratories, Benin City, Nigeria. The PCR was performed in a $25 \mu \mathrm{l}$ reaction mixture containing $12.5 \mu$ oneTaq one-step reaction master mix $(2 \times), 1.25 \mu$ of each forward primer $(20 \mu \mathrm{M}), 1.25 \mu \mathrm{l}$ of each reverse primer $(20 \mu \mathrm{M}), 5 \mu \mathrm{l}$ of nuclease-free water and $5 \mu$ of the DNA template was then added. The PCR was programmed as initial denaturation at $94{ }^{\circ} \mathrm{C}$ for $1 \mathrm{~min}$; denaturation at $94{ }^{\circ} \mathrm{C}$ for $15 \mathrm{sec}$, annealing temperature of the primers are shown in Table 1 for $30 \mathrm{sec}$; and extension at $72{ }^{\circ} \mathrm{C}$ for $1 \mathrm{~min}$, repetition of the denaturation step for 35 cycles; final extension at $72{ }^{\circ} \mathrm{C}$ for $5 \mathrm{~min}$ and final holding at $4{ }^{\circ} \mathrm{C}$. A total of $10 \mu \mathrm{l}$ of the amplified PCR products were analyzed on $1.0 \%$ agarose gel containing ethidium bromide in $1 \times$ Tris EDTA buffer. Electrophoresis was performed at $90 \mathrm{~V}$ for 40 mins with the EDVOTEK tetra source electrophoresis machine, Bethesda, USA. The targeted genes were visualized using Wealtec (USA) Dolphin-Doc UV transilluminator and photographed. Molecular weights were calculated using molecular weight standard marker (100-1517).

\section{DNA sequencing of isolate \\ Polymerase chain reaction with 16S rRNA}

Amplification and sequencing were done as described by Aka-gbezo et al., (2017), with the following modifications: PCR amplification of 16S rRNA was carried out using OneTaq one-step PCR mix (catalog No. NEB M0486S), supplied by New England Bio Labs Incorporation (Massachusetts), according to the manufacturer's specification. Forward and reverse primers were used to target 16s bacterial rRNA as shown in Table 1, using Aplied Biosystem 9700 thermal cycler PCR machine. The PCR was carried 
out, electrophoresis performed and targeted genes visualized as described above.

\section{PCR product cleaning and purification}

The PCR products were cleaned using Exo/SAP. Exo/SAP Master mix was prepared by adding $50.0 \mu \mathrm{l}$ Exonuclease I (NEB M0293) $20 \mathrm{U} / \mathrm{ul}$ and $200.0 \mu \mathrm{l}$ Shrimp Alkaline Phosphatase (NEB M0371) 1U/ul in a $0.6 \mathrm{ml}$ microcentrifuge tube. Exo/SAP Mix of $2.5 \mu \mathrm{l}$ was then added to $10.0 \mu \mathrm{l}$ of PCR Mixture, mixed well and was incubated at $37{ }^{\circ} \mathrm{C}$ for 30 minutes after which the reaction was stopped by heating at $95^{\circ} \mathrm{C}$ for 5 minutes. Purification was done with the ABI V3.1 Big dye kit according to manufacturer's instructions. The labeled products were then cleaned with the Zymo Seq clean-up kit. Sequencing Binding Buffer of $240 \mu \mathrm{l}$ was added to $20 \mu \mathrm{l}$ sequencing reaction which was the transferred to a Zymo-Spin ${ }^{\mathrm{TM}}$ IB-96 plate mounted onto a collection plate. The mixture was centrifuge at $3,000 \times g$ for 2 minutes. Sequencing Wash Buffer of $300 \mu \mathrm{l}$ was added to each well of the plate and centrifuge at 3,000 $\mathrm{x} g$ for 5minutes. $15 \mu \mathrm{l}$ of water was directly added to the column matrix of the filter plate. The Zymo-

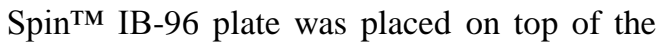
supplied 96-Well PCR plate and mount the assembly onto the Collection Plate which was then centrifuge at $3,000 \times g$ for 2 minutes to elute the DNA.

\section{Sequencing}

The Ultra-pure DNA was sequenced with ABI3500XL analyzer with a $50 \mathrm{~cm}$ array, using POP7 at Inqaba Biotechnical Industries Ltd (Hatfield, South Africa). Sequences data generated were analyzed with Geneious version 9.0.5 and phylogenetic tree were constructed using neighbor joining.

\section{Plasmid DNA extraction and documentation}

Pure Plasmid DNA isolation was carried out using a commercial plasmid isolation kit (ZR Plasmid Miniprep ${ }^{\mathrm{TM}}$ - Classic with Catalog Number D4O15) in accordance with the manufacturer's recommendation, following previously described procedures (Ehiaghe et al., 2016). Eight microliter extracted plasmids DNA and $2 \mu \mathrm{l}$ DNA loading dye were separated on a $0.8 \%$ agarose gel in tris-borate- EDTA buffer (TBEx1) $(\mathrm{pH}$ 8.2) stained with ethidium bromide. Electrophoresis was performed at $90 \mathrm{~V}$ for 60 mins with the EDVOTEK tetra source electrophoresis machine, Bethesda, USA. Plasmids were visualized using Wealtec (USA) Dolphin-Doc UV trans-illuminator and photographed. Molecular weights were calculated using molecular weight standard marker (500-48500 bp).

\section{Plasmid DNA curing}

In order to ascertain the possible genetic basis of the multiple drug resistance exhibited by the isolate, we carried out plasmid DNA curing analysis as earlier described (Ehiaghe et al., 2016). In summary, freshly prepared nutrient broth $(9 \mathrm{ml})$ was inoculated with $1 \mathrm{ml}$ overnight culture that was grown in Luria broth (Miller) containing antibiotics for 24 hours at $37{ }^{\circ} \mathrm{C}$. The resultant mixture was incubated for 4 hours to allow for minimal growth of the microorganisms. Aliquot of $1 \mathrm{ml}$ of the $10 \%$ sodium dodecyl sulphate curing agent was added to $9 \mathrm{ml}$ nutrient broth culture, and was incubated at 37 ${ }^{\circ} \mathrm{C}$ for 24 hours. The cured culture of $1 \mathrm{ml}$ was inoculated unto $9 \mathrm{ml}$ freshly prepared nutrient broth and incubated at $37{ }^{\circ} \mathrm{C}$ for 24 hours. The overnight broth culture was then used to carry out post-curing susceptibility test on MullerHinton agar plate with the necessary antibiotic discs placed and incubated for 24 hours at 37 ${ }^{\circ} \mathrm{C}$. 
Table 1: Summary of the primers used.

\begin{tabular}{|c|c|c|c|c|}
\hline $\begin{array}{l}\text { Names of } \\
\text { primer }\end{array}$ & $\begin{array}{l}\text { Primer } \\
\text { code }\end{array}$ & Primer sequence $5^{\circ}-3^{\prime}$ & $\begin{array}{c}\text { Annealing } \\
\text { Temperature } \\
\left({ }^{\circ} \mathrm{C}\right)\end{array}$ & $\begin{array}{c}\text { Expected } \\
\text { amplicon size } \\
\text { (bp) }\end{array}$ \\
\hline $\begin{array}{l}16 \mathrm{~S} \text { rRNA } \\
\text { bacteria universal } \\
\text { primer }\end{array}$ & $\begin{array}{c}27 \mathrm{~F}- \\
1492 \mathrm{R}-\end{array}$ & $\begin{array}{l}\text { AGAGTTTGATCMTGGCTCAG } \\
\text { CGGTTACCTTGTTACGACTT }\end{array}$ & 54 & 1200 \\
\hline $\begin{array}{l}\text { Ofloxacin } \\
\text { resistance gene }\end{array}$ & $\begin{array}{l}\text { gyrA F - } \\
\text { gyrA R }\end{array}$ & $\begin{array}{l}\text { ATGACTGATATCACGCTGCCA } \\
\text { ATAACGCATCGCTG CCGGTGG }\end{array}$ & 55 & 342 \\
\hline $\begin{array}{l}\text { Augmentin } \\
\text { resistance gene }\end{array}$ & $\begin{array}{l}\text { TEMU- } \\
\text { TEML- }\end{array}$ & $\begin{array}{l}\text { ATG AGT ATT CAA CAT TTC CG } \\
\text { CTG ACA GTT ACC AAT GCT }\end{array}$ & 50 & 867 \\
\hline $\begin{array}{l}\text { Augmentin } \\
\text { resistance gene }\end{array}$ & $\begin{array}{l}\text { SHVU2 } \\
\text { SHVL2 }\end{array}$ & $\begin{array}{c}\text { CCG CAG CCG CTT GAG CAA A } \\
\text { GCT GGC CGG GGT AGT GGT } \\
\text { GTC }\end{array}$ & 59 & 477 \\
\hline $\begin{array}{l}\text { Gentamicin } \\
\text { resistance gene }\end{array}$ & $\begin{array}{l}\text { aac(3)-II-F } \\
\text { aac(3)-II-R }\end{array}$ & $\begin{array}{l}\text { ACGCGGAAGGCAATAACGGA } \\
\text { TAACCTGAAGGCTCGCAAGA }\end{array}$ & 55 & 854 \\
\hline
\end{tabular}

\section{RESULTS}

Morphological and biochemical
characteristics of the isolate
Pure mucoid, pinkish (lactosefermenting) colonies were observed on MacConkey agar (Plate 1A). The isolate (2$3 \mathrm{~mm}$ diameter) was non-haemolytic on blood agar. All 3 strains of the isolate were typically Gram negative, motile rod-shaped bacteria, which were lipase positive but oxidase, gelatinase, deoxyribonuclease, indole and urease negative. They utilized citrate as sole source of carbon and were $\mathrm{H}_{2} \mathrm{~S}$, methyl red, arginine, and ornithine decarboxylase positive. They produced acid and gas from glucose, lactose, sucrose, maltose, xylose, trehalose and cellobiose but were negative dulcitol, inositol, sorbitol, adonitol, arabinose, raffinose and melibiose. They did not hyderolize gelatin and deoxyribonucleic acid (Table 2).

\section{Susceptibility profile of strains}

The antibiotic susceptibility profile showed that the three bacteria strains isolated were highly susceptible to imipenem and moderately sensitive to nitrofurantoin but resistant to all other antibiotics used (Plate 1B and Table 3).

\section{Plasmid profiling/curing}

As shown in Plate 3, the plasmid profile of the isolate revealed that strains $U$, U2, U3 were positive for plasmid DNA with each band at $48.5 \mathrm{~kb}$. The susceptibility patterns of the three strains remained the same post-plasmid curing as shown in Table 3.

Molecular detection of gyrA, SHV, TEM and aac(3)-II resistance genes on plasmid DNA and genomic DNA extracts

The study revealed that the isolate expressed gyrA resistance gene with bands at 342 and 400 bp for both plasmid DNA and genomic DNA. TEM resistance gene was positive with band at $477 \mathrm{bp}$ for genomic DNA but negative for plasmid DNA. SHV resistance gene was positive at $477 \mathrm{bp}$ for plasmid DNA but negative genomic DNA. However, aac(3)-II resistance gene was negative for both plasmid and genomic DNA (Plates 2 and 4).

\section{Molecular identification of isolate}

Analysis of sequence data using Geneious package (version 9.0.5) with Maff alignment revealed that the isolate is closely related to Cedecae davisae as shown in the phylogenetic tree (Figure 1). 
A

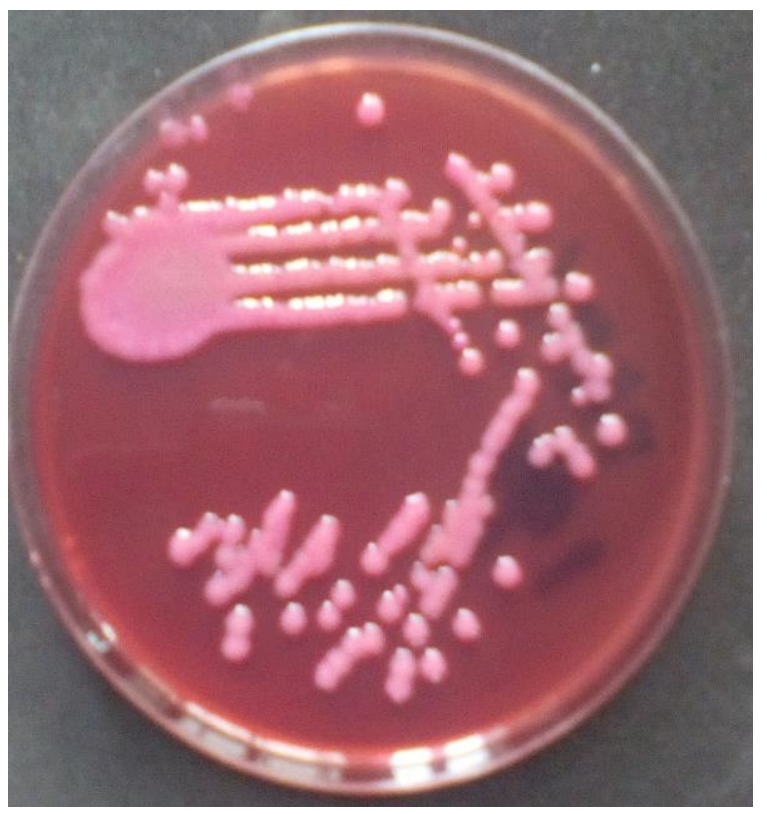

B

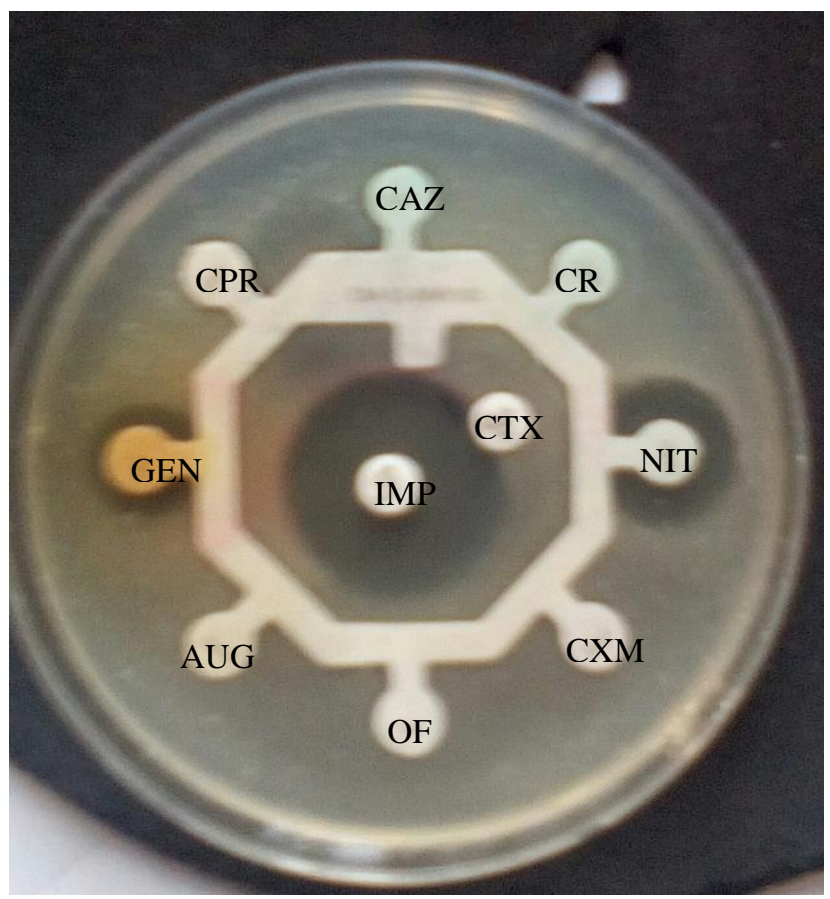

Plate 1 (A \& B): Colonies and antibiogram respectively of a multidrug resistant Cedecea davisae isolated from a 76-year old man with post-prostatectomy UTI. The isolate is highly sensitive to imipenem (IMP), moderately sensitive to nitrofurantoin (NIT) and resistant to the other antibiotics.

Table 2: Biochemical characterization of 3 strains isolate from urine.

\begin{tabular}{lc}
\hline Test & Number positive \\
\hline Indole & $0 / 3$ \\
Methyl red & $3 / 3$ \\
Voges-Proskauer & $0 / 3$ \\
Citrate & $3 / 3$ \\
H2S & $3 / 3$ \\
Lipase & $3 / 3$ \\
Oxidase & $0 / 3$ \\
Urease & $0 / 3$ \\
Gelatinase & $0 / 3$ \\
Phenylalanine & $0 / 3$ \\
Deoxyribonuclease & $0 / 3$ \\
Lysine & $0 / 3$ \\
Arginine & $3 / 3$ \\
Ornithine & $3 / 3$ \\
ONPG & $3 / 3$ \\
Mortlity & $3 / 3$ \\
D-Glucose (acid and gas) & $3 / 3$ \\
Maltose & $3 / 3$ \\
Lactose & $3 / 3$ \\
\hline
\end{tabular}




\begin{tabular}{ll}
\hline Sucrose & $3 / 3$ \\
Salicin & $3 / 3$ \\
Dulcitol & $0 / 3$ \\
Adonitol & $0 / 3$ \\
i-Inositol & $0 / 3$ \\
D-Sorbitol & $0 / 3$ \\
L-Arabinose & $0 / 3$ \\
Raffinose & $0 / 3$ \\
D-Xylose & $3 / 3$ \\
Trehalose & $3 / 3$ \\
Cellobiose & $3 / 3$ \\
Melibiose & $0 / 3$ \\
\hline
\end{tabular}

Table 3: Susceptibility profile of isolate.

\begin{tabular}{ccccccccccc}
\hline $\begin{array}{c}\text { Isolated Cedecea } \\
\text { davisae strains }\end{array}$ & \multicolumn{10}{c}{ Antibiogram } \\
\cline { 2 - 10 } & NIT & CIP & OFX & CAZ & CRX & AUG & CXM & GEN & IMP & CTX \\
\hline $\mathrm{U} 1$ & $\mathrm{~S}$ & $\mathrm{R}$ & $\mathrm{R}$ & $\mathrm{R}$ & $\mathrm{R}$ & $\mathrm{R}$ & $\mathrm{R}$ & $\mathrm{R}$ & $\mathrm{S}$ & $\mathrm{R}$ \\
$\mathrm{U} 2$ & $\mathrm{~S}$ & $\mathrm{R}$ & $\mathrm{R}$ & $\mathrm{R}$ & $\mathrm{R}$ & $\mathrm{R}$ & $\mathrm{R}$ & $\mathrm{R}$ & $\mathrm{S}$ & $\mathrm{R}$ \\
$\mathrm{U} 3$ & $\mathrm{~S}$ & $\mathrm{R}$ & $\mathrm{R}$ & $\mathrm{R}$ & $\mathrm{R}$ & $\mathrm{R}$ & $\mathrm{R}$ & $\mathrm{R}$ & $\mathrm{S}$ & $\mathrm{R}$ \\
\hline
\end{tabular}

$\mathrm{R}$ - Resistant, $\mathrm{S}$ - Sensitive.

nitrofurantoin (NIT), ciprofloxacin (CIP), ofloxacin (OFX), ceftazidime (CAZ), cefuroxime (CRX), augmentin (AUG), cefixime (CXM), gentamicin (GEN), imipenem (IMP) and ceftriaxone (CTX).

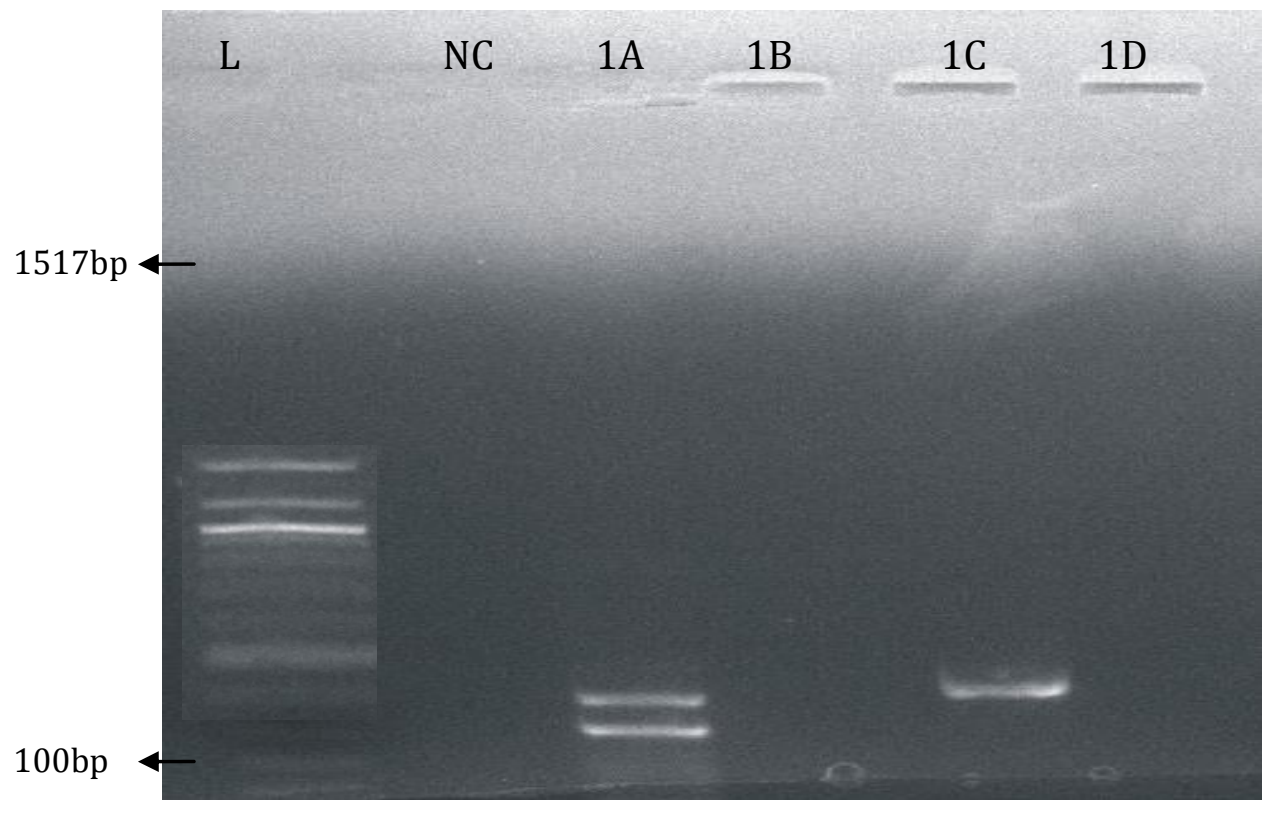

Plate 2: Polymerase chain reaction result of antibiotic resistance genes harboured by Cedecea davisae isolated from urine specimen analyzed with $1.0 \%$ agarose gel electrophoresis stained with ethidium bromide. L is 100bp-1517 bp DNA ladder (molecular marker). Lane 1A is positive for gyrA resistance gene with double bands at 342 and $400 \mathrm{bp}$ respectively, lane $1 \mathrm{~B}$ is negative for TEM resistance gene while lane $1 \mathrm{C}$ is positive for SHV resistance gene with band at $477 \mathrm{bp}$. Lane 1D was negative for ac(3)-II resistance gene while lane NC is a no DNA template control. 
D. E. AGBONLAHOR et al. / Int. J. Biol. Chem. Sci. 12(2): 676-688, 2018

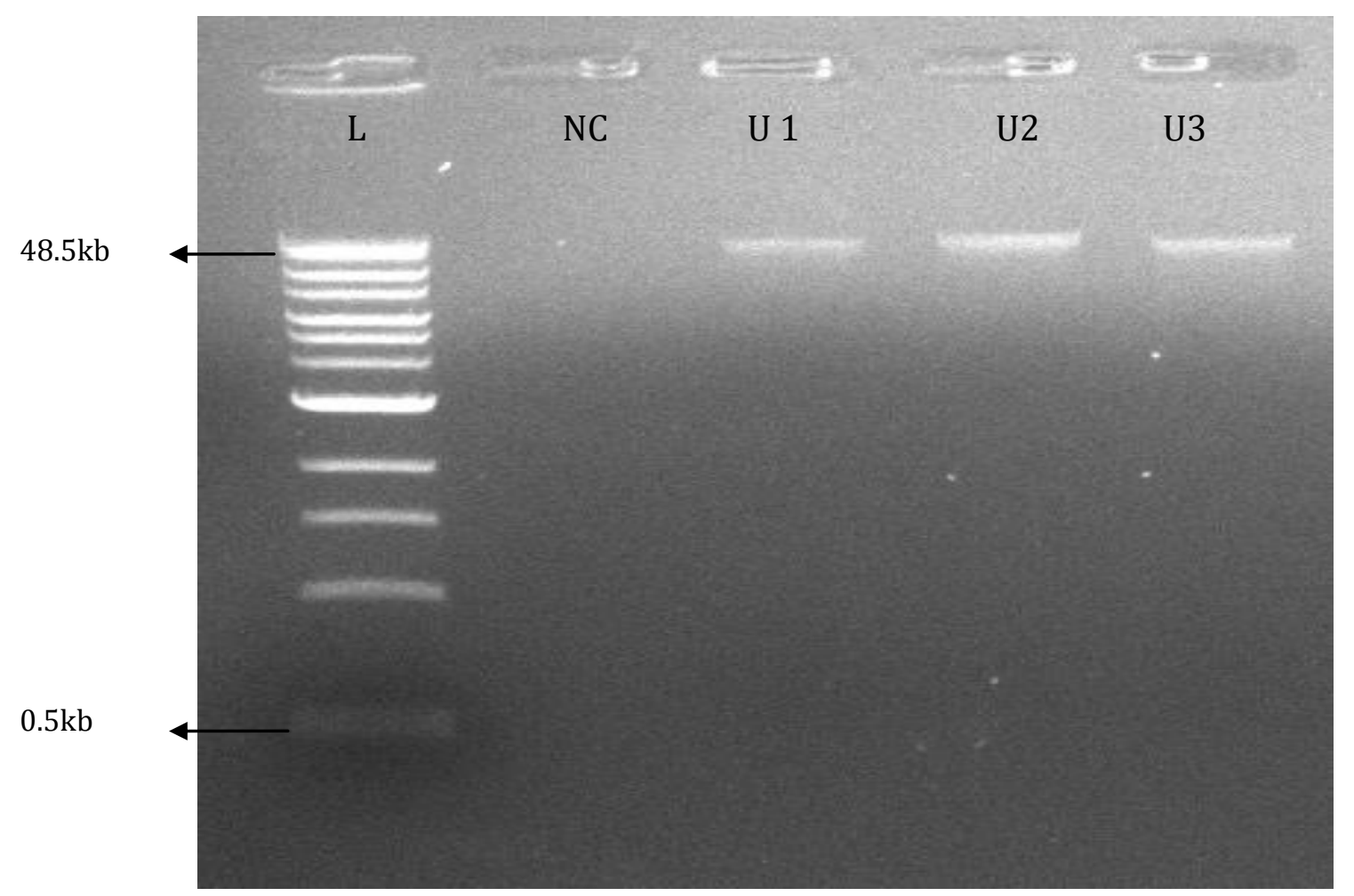

Plate 3: Plasmid profile of Cedecea davisae isolate analyzed with $0.8 \%$ agarose gel electrophoresis stained with ethidium bromide. $\mathrm{L}$ is $0.5 \mathrm{~kb}-48.5 \mathrm{~kb}$ DNA ladder (molecular marker). Strains U1, U2 and U3 are positive for plasmid DNA with bands at $48.5 \mathrm{~kb}$. NC is a no plasmid DNA template control. 


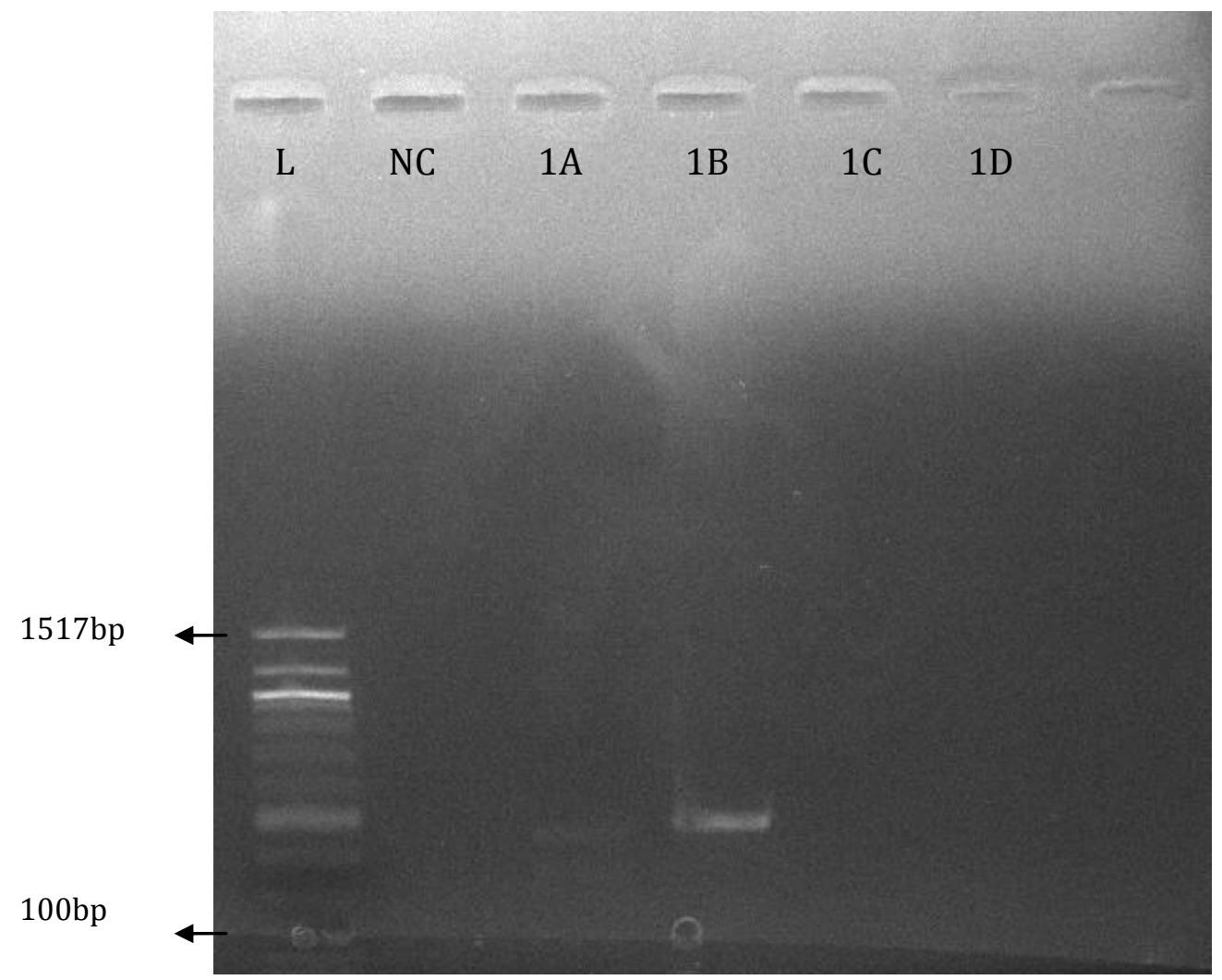

Plate 4: PCR result of plasmid DNA extracted from Cedecea davisae, analyzed with $1.0 \%$ agarose gel electrophoresis and stained with ethidium bromide. $\mathrm{L}$ is 100 bp -1517 bp DNA ladder (molecular marker). Lane 1A is positive for ofloxacin (gyrA) resistant gene with double bands at 342 and 400 bp respectively; lane 1B is positive for augmentin (SHV) resistant gene with band at $477 \mathrm{bp}$ while lanes $1 \mathrm{C}$ and 1D are negative for augmentin (TEM) resistance gene and gentamicin (aac(3)-II) resistance gene respectively. $\mathrm{NC}$ is a no plasmid DNA template control. 


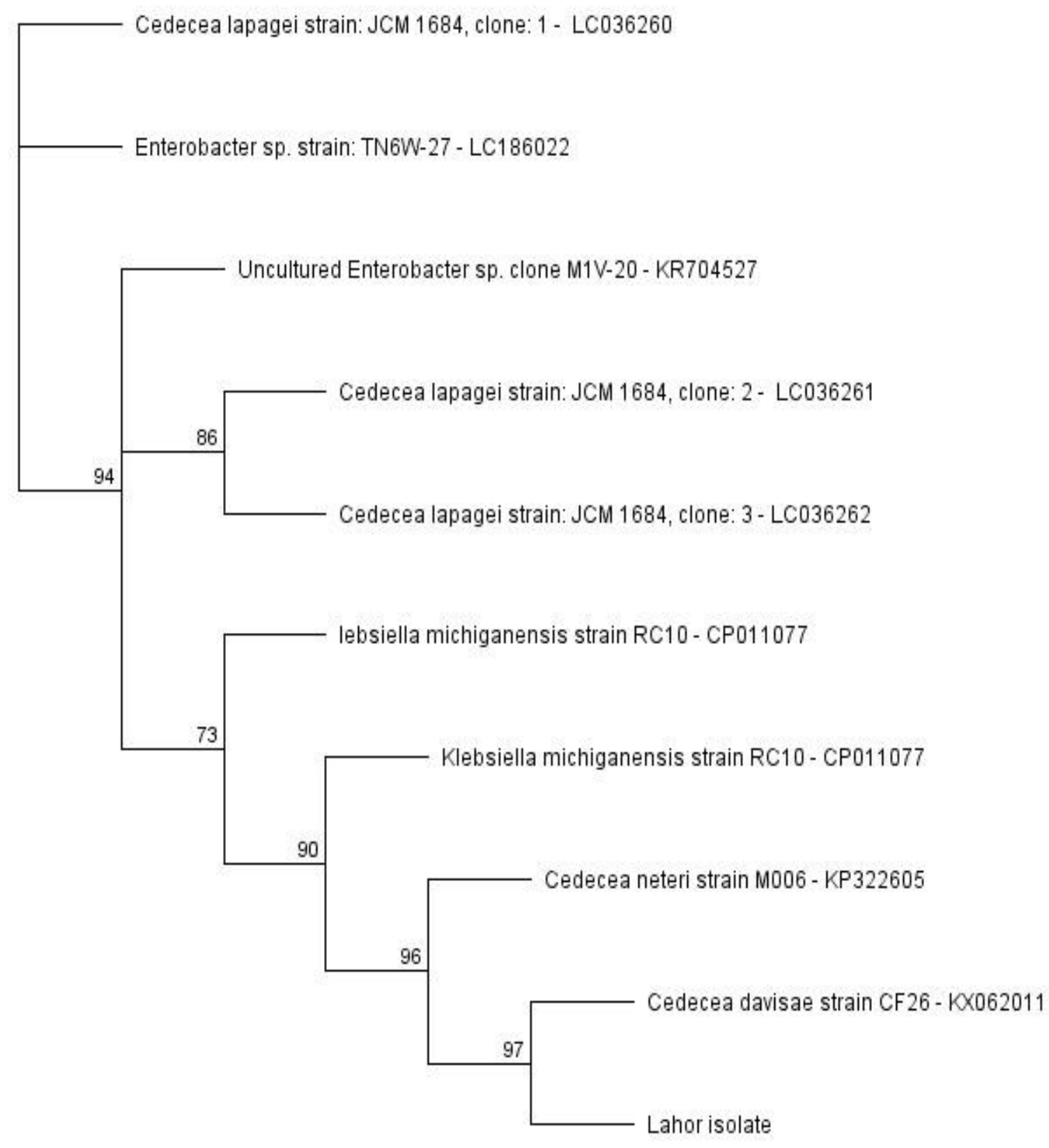

Figure 1: Phylogenetic analysis of a bacterium based on the nucleotide sequence of part of the 16S rRNA nucleotide sequence of the Isolate. The phylogenetic tree was constructed by the NeighborJoining method program in the Geneious package (version 9.0.5). The numbers at the forks show the numbers of occurrences of the repetitive groups to the right out of 100 bootstrap samples. Lahor isolate has similar sequence with Cedecea davisae strain CF26 with accession number KX062011. 


\section{DISCUSSION:}

About $50 \%$ of the Cedecea infections so far reported in literature have been ascribed to Cedecea davisae (Dalamaga et al., 2008a; Abate Qureshis and Mazumber, 2011; Mawardi et al., 2013; Peretz et al. 2013; Akinosoglou et al., 2015). Most of the cases were associated with bacteremia (Dalamago et al., 2008a; Dalamago et al., 2008b; Abate et al., 2011; Akinosoglou et al., 2012; Peretz et al., 2013). Cedecea spp. rarely cause urinary tract infections and the only reported case so far was due to Cedecea lapagei (Cekin et al., 2014). The current report is the first time Cedecea davisae is incriminated as aetiologic agent of UTI.

The strains of Cedecea davisae isolated from three consecutive urine specimens from the patient had similar biochemical profile with those earlier described by Michael and Abbatt (Michael and Abbatt, 2006). They uniformly produced acid and gas from glucose, xylose and sucrose. They were oxidase, indole, $\mathrm{H}_{2} \mathrm{~S}$ and urease negative, motile, Gram negative rods, which produced lipase and decarboxylated arginine and ornithine. Based on the above profile, we initially misidentified the isolate as Serratia spp. until our molecular characterization (phylogenetics) results showed that the isolate has similar DNA sequence with Cedecea davisae strain CF26, with accession number KX062011 (Figure 1). This is a rarely seen bacterium in clinical laboratories and may be difficult to recognize and characterize, particularly in low-resource laboratories. Moreover, it is conceivable that Laboratorians inadvertently dismiss this rare organism as contaminants in clinical specimens. These may, in part, explain the paucity of reports about the organism in the literature.

The isolate showed very high degree of resistance to antibiotics that are commonly prescribed in our hospitals and clinics in Nigeria. As shown in Table 3, the organism was sensitive to only imipenem and nitrofurantoin but resistant to all other antibiotics. This is consistent with previous reports that Cedecea davisae infections can be difficult to treat due to antibiotic resistance of the organism (Dalamago et al., 2008a; Dalamago et al., 2008b; Peretz et al., 2013). For good therapeutic practices and costeffectiveness, it should be mandatory to establish the antibiogram of clinical isolates before commencement of antibiotic treatment of patients.

The isolate was confirmed to harbour some antibiotic resistance genes which were plasmid-mediated, chromosomal-mediated or both. It harboured gyrA resistance gene, which codes for resistance to ofloxacin. This was found on both plasmid and genomic DNA extracts, suggesting that gyrA resistance gene was both plasmid and chromosomal-borne. However, SHV gene, which codes for augmentin resistance (Keith et al., 2014), was detected only on the plasmid DNA, while TEM resistance gene, which also codes for augmentin resistance, was detected only on the genomic DNA. Interestingly, the isolate failed to express aac(3)-II gene. The gene was neither found on the plasmid DNA nor on the genomic DNA extracts, yet we reported the organism as resistant to gentamicin. This suggests that gentamicin resistance is possibly coded for, by an additional gene or that we erroneously reported the isolate as resistant to the drug, because of the narrow zone of inhibition observed in-vitro (Plate 1B). The above findings however confirm earlier reports that Cedecea davisae could be highly resistant to several antibiotics (Dalamago et al., 2008a and Dalamago et al., 2008b; Peretz et al., 2013).

It is also pertinent to note that the possession of plasmid, which bears multidrug resistance genes by this organism, suggests that this isolate could transfer its genetic materials to other susceptible bacteria in the same ecosystem. This portends great public health danger, as such a multidrug resistant pathogen could lead to infections that would be similarly difficult to treat.

\section{Conclusion}

This report has described the first isolation and characterization of a multidrug resistant Cedecea davisae from a case of recurrent urinary tract infection in a post- 
prostatectomy patient in Nigeria. Apart from the report where Cedecea lapagei was earlier isolated from urine, this report appears to be the second case of urinary tract infection caused by Cedecea spp. The emerging clinical significance of this hitherto rare organism in human infections is worthy of note.

\section{COMPETTING INTERESTS}

Authors declare that they have no competing interests.

\section{AUTHORS' CONTRIBUTIONS}

This work was carried out in collaboration between all the authors. DEA, JIE, OAE, AFE designed the study. JIE, OAE, AFE, FEO, RII, ECO, PEI. Manage and analyzed the samples. MOO, SA, MST managed the literature search. All the authors read and approved the final manuscript.

\section{ACKNOWLEDGEMENTS}

The authors gratefully acknowledge the excellent secretarial assistance by $\mathrm{Mr}$. Imasuen E. Felix.

\section{REFERENCES}

Abate G, Qureshis S, Mazumber SA. 2011. Cedecea davisae bacteremia in a neutropenic patient with acute myeloid leukemia. J. Inf., 63: 83 - 85. DOI: 10.1016/j.jinf.2011.04.007.

Agca H, Bozkurt M. 2014. A pneumonia case caused by Cedecea lapagei. J. Clin. Anal. Med., 5(2): 147-148. DOI: 10.4328/JCAM.757.

Aka-gbezo S, Konan AG, N'Cho MPA, Achi, P, Koffi-Nevry R, Koussemon-Camara M, Bonfoh B. 2017. Screening of antimicrobial activity of lactic acid bacteria isolated from amiango baca slurry, a spontaneously fermented maize product used in Cote d'Ivoire. Int. J. Biol. Chem. Sci., 11(6): 2616-2629. DOI: http://ajol.info/index.php/ijbcs

Akinosoglou K, Perperis A, Siagris D, Goutou P, Spiliopoulou I, Gogos CA, Markos M. 2012. Bacteremia due to Cedecea davisea in a patient with sigmoid colon cancer: a case report and brief review of the literature. Diag. Microbial Infect. Dis., 74(3): 303-306. DOI: 10.1016/j.diagmicrobio.2012.06.019.

Biswal I, Hussan NA. 2015. Cedecea lapagei in a patient with malignancy: Report of a rare case. J. Can. Res. Therapy., 11: 646. DOI: 10.4103/0973-1482.147736.

Cekin Y, Kizilates, Dolus N, Oztoprak Cekin AH. 2014. The first urinary tract infection caused by Cedecea lapagei: a case report and review of the literature. Gaziantep Med. J., 20(2): 193 - 195. DOI: $10.5455 / \mathrm{GMJ}-30-153282$.

Cheesbrough M. 2006. Microbiological tests. In District Laboratory Practice in Tropical Countries $\left(2^{\text {nd }}\right.$ edn). Cambridge University Press: UK; 189.

Clinical and Laboratory Standards Institute. 2009. Performance Standards for Antimicrobial Susceptibility Testing,' $18^{\text {th }}$ informational supplement. Clinical and Laboratory Standards Institute, 114.

Dalamaga M, Vrioni G. 2011. Cedecea. Molecular detection of human bacterial. Patho., 817-825. DOI: 10.9790/08531511088485.

Dalamago M, Pantelaki M, Karmaniolas K, Matekovits A, Daskalopoulou K. 2008a. Leg ulcer and bacteremia due to Cedecea davisea. Eur. J. Dermatol., 18(2): 204205. DOI: www.iosrjournals.org.

Dalamago M, Karmaniolas K, Arsenis G, Pantelaki M, Daskalopoulou K, Papadavid E, Migdalis I. 2008b. Cedecea lapagei bacteremia following cement-related chemical burn injury. Burns. 34: $1205 \quad-1207$. DOI:10.1016/j.burns.2007.09.001

Ehiaghe FA, Ehiaghe IJ, Agbonlahor DE, Oviasogie FE, Etikerentse SMO, Nwobu RAU, Akinshipe BO, Ikusemore AI, Aladenika ST, Enwa FO. 2013. Plasmid profiling and curing analysis of fluoroquinolone multidrug resistant Pseudomonas aeruginosa. Open J. Med. Micro., 3: 201 - 205. DOI: $10.4236 /$ ojmm.2013.33030

Ehiaghe JI, Nwobu RAU, Ehiaghe FA, Agbakoba NR, Agbonlahor DE, Uwabor CI. 2016. Plasmid Profiling of 
Multidrug Resistant Bacteria Isolates from Surgical Site Infection in Nigeria. Am. J. Biotech. Mol. Sci., 5(1): 23-32. DOI: http://www.sclhub.org/AJBMS

Keith SK, Howard SG, Mitchell JS, Lata V, Youlin QI, Paola CD, Matthew HS, Greg S, Kamile R; Fred CT. 2004. Variety of $\beta$-Lactamases Produced by AmoxicillinClavulanate-Resistant Escherichia coli Isolated in the Northeastern United States. Antimicrob. Agents Chemoth., 48(5): $\quad 1520-1525 . \quad$ DOI: 10.1128/AAC.48.5.1520-1525.2004

Mawardi H, Pavlakis M, Mandelbrot D, Woo SB. 2010. Sirolimus oral ulcer with Cedecea davisea super infection. Transpl. Infect. Dis., 12: 446-450. DOI: 10.1111/j.1399-3062.2010.00514

Michael JJ, Abbatt SL. 2006. The Enterobacteriaceae $\left(2^{\text {nd }}\right.$ edn). ASM Press: Washington DC; 411.

National Committee for Clinical Laboratory Standards. 2003. Methods for disk diffusion: approved standard M2A8: performance standards for NCCLS antimicrobial disc susceptibility tests.

Olugbue V, Onuoha S. 2011. Prevalence and antibiotic sensitivity of bacterial agents involved in lower respiratory tract infections. Int. J. Biol. Chem. Sci., 5(2): 774-781.

DOI: http://indexmedicus.afro.who.int.

Peretz A, Simsolo C, Farber E, Roth A, Bratsky D, Nakhoul F. 2013. A rare bacteremia caused by Cedecea davisae in patient with chronic renal disease. Am. J. Case Rep., 14: 216-218. DOI: https://www.semanticscholar.org

Yetkin G, Ay S, Kayaba U, Gedik E, Gucluer N, Caliskan A. 2008. A pneumonia case caused by Cedecea lapagei. Mikrobiyol. Bul., 42: 681-684. DOI: https://www.ncbi.nlm.nih.gov/pubmed. 